\title{
OBITUARY
}

\section{Ludwig Teleky}

Industrial medicine has lost a leading international figure and a beloved fellow-worker through the death of Dr. Ludwig Teleky. He was born in Vienna, the son of Hermann Teleky, M.D. He died in the Jewish Memorial Hospital, New York, on August 20, 1957, aged 85 years.

He was lecturer in social medicine in the University of Vienna from 1909 to 1919 . From 1919 to 1932 he was Director of the Postgraduate Academy of Public Health and Industrial Medicine at Dusseldorf, and at the same time Medical Inspector of Factories for the Rhineland, and a member of the Central Council for Health in Berlin. In 1932 in the Nazi persecution of the Jews he was deprived of these appointments and returned to Vienna.

He was a founder member of the Permanent International Commission on Industrial Medicine in 1906, and in 1951 was elected an honorary life member of the Commission in recognition of his eminence.

Teleky attended the 8th International Congress on Industrial Medicine at Frankfurt in 1938. This Congress was interrupted by the Munich crisis and the delegates dispersed. It was necessary for Teleky's safety for his friends to get him over the border into Switzerland. Friends in Austria and America then arranged for him to go to the United States of America, where he was appointed to a lectureship in the University of Chicago, which he held from 1939 to 1944.

In 1944 Dr. Leonard Greenburg, now Commissioner of the Air Pollution Control Department of New York, invited Teleky to work with him in the Labour Division of the New York State Department of Industrial Hygiene.

While in New York Teleky devoted much of his time to writing and from his pen flowed many articles and a number of books upon occupational health. He edited the Encyclopaedia of Industrial Diseases published by the International Labour. Office. His book " The History of Factories and their Hygiene" was published by the Columbia Press in 1948, and "Gewerbliche Vergiftungen" was published by Springer-Verlag, Berlin, in 1955.

The Grand Cross of Merit was conferred on Dr. Teleky by President Heuss of the German Federal Republic, and in 1952 in a new part of Hamm, one of the ancient Hanse towns of Germany, a street was called by his name.

His wife died in 1953 . He is survived by two daughters, Anna, a worker in social medicine now living in Vienna, and Agnes, a Doctor of Philosophy of the University of Frankfurt, who is engaged in social science work in London.

T. E. A. Stowell
Professor E. L. Collis, C.B.E., D.M., M.R.C.P.

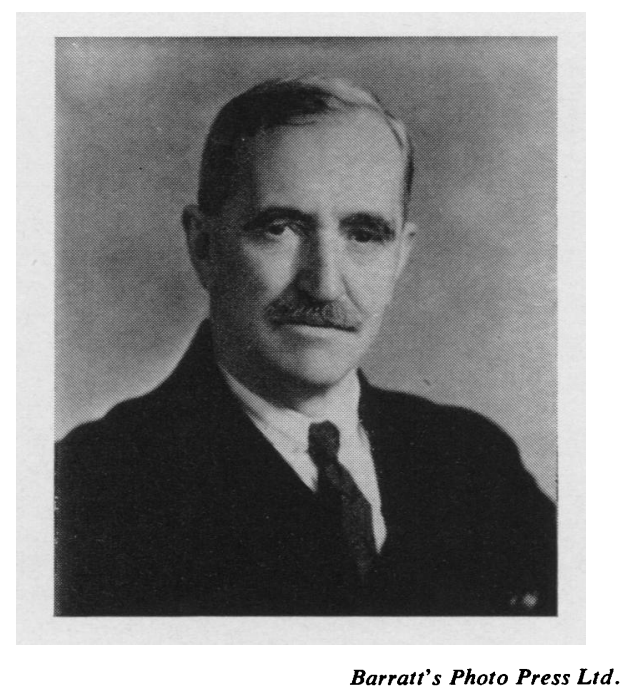

Professor E. L. Collis, Emeritus Professor of Preventive Medicine in the University of Wales, died in hospital at Forres, Morayshire, on October 1, 1957, aged 86 years. By his death Great Britain has lost one of its pioneers of industrial medicine.

Edgar. Leigh Collis was born at Stourbridge on November 25, 1870, the son of W. B. Collis, J.P. From Stourbridge Grammar School he went on to Charterhouse, and then to Keble College, Oxford. A notable sportsman in those days, he was president of the Oxford University Swimming Club and represented the university in athletics against Cambridge in 1892 and 1893, tying for first place in the hurdles in the latter year. After gaining first class honours in the Natural Science School at Oxford he went to St. Thomas's Hospital for his clinical studies, qualifying in 1896 and graduating B.M., B.Ch. in the following year. He proceeded to the D.M. in 1919, and became M.R.C.P. in 1920. For the first 10 years or so of his professional life he was a general practitioner in Stourbridge, where he was certifying factory surgeon and on the staff of the Corbett Hospital.

In 1908 he joined the staff of the Factory Department of the Home Office as a medical inspector of factories, and soon became a leading authority on pneumoconiosis, the subject of his Milroy Lectures in 1915. He had also made various investigations on behalf of Home Office departmental committees, including the study of heat stress in hot industries.

When, early in the first World War, the Minister of 
Munitions set up the Health of Munition Workers Committee, Collis was appointed a member of it, and in 1917 he became Director of Welfare and Health in the Ministry.

Collis and his colleagues on the war-time committee were convinced of the pressing need for the application of physiological science in industry and recommended that when the war ended some arrangements should be made for continuing studies such as they had initiated. As a result of that recommendation the Industrial Fatigue Research Board was set up in 1918 and Collis was one of its first members. In that capacity he was able to advise on the organization and direction of research into the physiological and psychological problems of industry.

In 1919 he was appointed Talbot Professor of Preventive Medicine at the Welsh National School of Medicine at Cardiff and there he continued his studies of pneumoconiosis and took an active interest in the improvement of working conditions in coal-mines and in miners' welfare. At about this time he became a member of the Miners' Welfare Commission on which he served for over 30 years.

By this time Collis had an international reputation as an authority on industrial hygiene. From 1922 to 1936 he was British Editor of the Journal of Industrial Hygiene. In 1924 he gave the Harben Lectures on "Phthisis and Industrialism ", and in 1926 he gave a course of lectures at Harvard University. He was co-author with Professor Major Greenwood of the book "The Health of the Industrial Worker" which was published in 1921.

Professor Collis retired from his university appoint- ment in 1933 and was made emeritus professor. He went to live in Lossiemouth, Morayshire, where he became a Justice of the Peace. In 1937 he was appointed C.B.E. and in 1954 the Society of Apothecaries conferred on him the Diploma in Industrial Health, honoris causa. He never lost his interest in industrial medicine and in spite of his advanced age he was a regular contributor to the Bulletin of Hygiene until the time of his death. During the last war he served as a medical officer in the Home Guard and was appointed Lieutenant-Colonel when he was about 70 years of age. This appointment gave him great pleasure and considerable amusement.

From 1919 to 1921 he was my Director and thereafter we kept in close touch with each other until several years after he had retired from his chair at Cardiff. Collis's wide knowledge of industry made him a particularly valuable adviser on field investigations, and a discussion of one's problems never failed to bring stimulating suggestions from him. He was kind and considerate and always ready to advise a junior worker. He was a good critic and his criticisms were always constructive. He was intensely interested in the human problems of industry and his earnestness was tempered by a keen sense of humour. Besides being educative, work with him provided many amusing moments.

He married Barbara Shields, daughter of Principal Fairbairn, of Mansfield College, Oxford, and she survives him.

His passing will bring deep regret to all those who are fortunate enough to have known him.

ThOMAS BeDFord 